\title{
Power, Control and Optimization
}

\section{Pandian Vasant ${ }^{1 *}$, Sebastian K Francis ${ }^{2}$ and Vu Trieu Minh ${ }^{3}$}

${ }^{1}$ Department of Fundamental and Applied Sciences, Universiti Teknologi Petronas, Malaysia

${ }^{2}$ APEX Human Capital Development Consultancy, Malaysia

${ }^{3}$ Department of Power Systems, Ho Chi Minh City University of Technology, Vietnam

Global Journal Technology and Optimization is a leading global journal in the area of Power, Control and Optimization for innovative, novel, original and high quality scientific and engineering global research. The editorial board members are from international research scholars in the research field of technology and optimization. These global research scholars are very actively involved in publishing very high quality research papers in the global conference of Power Control Optimization since the year 2008. The editor is strongly believe and very confident in creating a new global research platform to all the researchers, scientist, managers, educationist and decision makers from all over the world.
The editorial team sincerely would like to invite researchers across the globe to submit their research articles, review and survey articles to the GJTO journal. PCO'2013 global conference will take place in Prague, Czech Republic on 25-27th August 2013, in Kota Kinabalu, Sabah, Malaysia on 7-9th October 2013 and Rangoon, Burma on 2-3rd December 2013. Please kindly visit the website of PCO'2013 at http:// www.pcoglobal.com. The conference proceedings published by AIP, USA and indexed in SCOPUS and Web of Science of ISI Thomson Reuters. The best selected papers after the review report will be published in GJTO journal.
*Corresponding author: Pandian Vasant, Department of Fundamental and Applied Sciences, Universiti Teknologi Petronas, Malaysia, Tel: +60103819267 E-mail: vasantglobal@gmail.com

Received August 15, 2013; Accepted August 16, 2013; Published August 21, 2013

Citation: Vasant P, Francis SK, Minh VT (2013) Power, Control and Optimization Global J Technol Optim 4: e102. doi: 10.4172/1410-3217.1000e102

Copyright: $\odot 2013$ Vasant $P$, et al. This is an open-access article distributed under the terms of the Creative Commons Attribution License, which permits unrestricted use, distribution, and reproduction in any medium, provided the original author and source are credited. 